\title{
Heidegger's Fundamental Ontology and the Problem of Animal Life
}

\author{
Josh Hayes
}

I believe- that none of the conventionally accepted limits between the so-called human being and the so-called animal one, none of the oppositions, none of the supposedly linear and indivisible boundaries-resist a rational deconstruction... (Derrida, Rogues: Two Essays on Reason).

\section{Rational Animals}

The question of animal cognition, which has been at the forefront of several studies in animal behavior over the last three decades, has taken on a renewed sense of urgency with the results of the most recent research devoted to birds. A particular series of experiments involving ravens has again prompted both scientists and philosophers to reexamine the boundaries of animal cognition. The first experiment by the behavioral biologist Thomas Bugnyar concerned two male ravens who were tested for their capacity to find bits of cheese hidden in film canisters. ${ }^{1}$ While the more intelligent but subordinate raven, Hugin, would consistently find the cheese, the more dominant raven, Munin, would rush in and steal his reward. So Hugin devised a strategy to pry open and pretend to eat from the empty canisters in order to mislead or deceive Munin from finding the cheese. If Munin followed Hugin and chased him away from the empty canisters, then Munin would have the advantage of finding those canisters that contained the cheese. The results of this experiment raise a perplexing question regarding the capacity of 
Hugin to recognize the difference between knowing where the cheese was hidden and knowing how to deceive Munin. How could Hugin decipher the intentions of Munin to eat the cheese? In a similar experiment, the ravens observed Thomas Bugnyar and his colleague Bernd Heinrich gaze at a spot on the other side of a barrier. In this case, all the ravens hopped off their perches to observe the curious gaze of the scientists. ${ }^{2}$ This experiment begs the question concerning how the ravens could be aware that the scientists were perceiving something that they could not. How are scientists and philosophers to characterize this capacity for both curiosity and deception if not by recourse to cognition? I think we have to begin by investigating whether or not there is a sufficient condition which entails true cognition. The Oxford researcher, Marion Stamp Dawkins, argues that true cognition happens when an animal solves a problem under novel conditions. The problem-solving capacity of ravens when confronted with both unique situations might lead us to believe that the true cognition we sometimes attribute exclusively to humans seems to extend far beyond our species. A host of other previous experiments have proven how mammals, including chimpanzees, elephants, dolphins, and dogs also share attributes of true cognition. ${ }^{3}$ From a precursory glance at the following experiments, we are left with a perplexing question concerning the degree of analogical difference between human and animal cognition. To analogically attribute these same cognitive capacities to animals requires that we consider our own species as existing within a biological continuum with such animals. This position challenges us to rethink our ethical relation to nonhuman animals and ultimately leads us to investigate the nature of the animality which conditions and informs our rationality. Unfortunately, the history of philosophy has taught us to think otherwise.

In both the analytic and continental traditions of philosophy, there remains a common tendency unquestionably to affirm the sharp division between nonhuman animals and human 
beings on the basis of language. The claim shared by both traditions is that there can be neither thoughts nor thinking without language. The dependence of language on thinking appears to be self-evident. How can we distinguish speaking from expressing thoughts? In his essay, "Thought and Talk," Donald Davidson argues that thinking constituted by a complex pattern of background beliefs depends upon speech. ${ }^{4}$ Moreover, the attribution of beliefs is inseparable from the capacity to interpret speech. I can determine what another speaker has chosen and interpret the purposes of their intentions only if I have the capacity to assign a relevant set of beliefs to that speaker. In other words, I have to be a member of that speech community with a capacity to attribute beliefs in order to interpret speech: "The dog, we say, knows that his master is home. But does it know that Mr. Smith (who is his master), or that the president of the bank (who is that same master), is home? We have no real idea how to settle, or make sense of, these questions" (Davidson 163). It is impossible to have sufficient grounds for ascribing beliefs to nonhuman animals who lack the capacity of uttering sentences. Davidson poses the question of whether or not a nonhuman animal can have any grounds whatsoever for ascribing beliefs, yet ultimately concedes that they cannot since someone can only have a belief if he or she understands the possibility of being mistaken by conceptually grasping the difference between true and false beliefs. Nonhuman animals do not have the capacity to distinguish between true and false beliefs and therefore cannot be mistaken.

\section{Heidegger's Problem}

The twentieth century continental philosopher, Martin Heidegger, utilizes the same modus operandi to justify the absence of language in nonhuman animals. Since nonhuman animals lack Davidson's cognitive capacity of belief ascription, they lack conceptual 
understanding, i.e., the capacity to apprehend their environment $a s$ an environment. Heidegger's 1929-1930 lecture course, The Fundamental Concepts of Metaphysics: World, Solitude, Finitude, provides an elaborate justification for such a conclusion by relying upon a set of ontological categories to distinguish animals from human beings. The human being is "world-forming" (weltbildend), the stone is altogether "without world" (weltlos), and the animal is "poor-inworld" (weltarm). ${ }^{5}$ Heidegger expresses the poverty of the animal by explaining how the animal is essentially captive to its environment. Animals behave (sich benehmen) by responding to certain instinctual drives of flight and pursuit which allow them to move within their environment. However, they can never come to comprehend or understand their environment as an environment. Animals are limited by their capacity to perceive and therefore lack the conceptual capacity to comprehend what they encounter as having any objective existence. For example, the lizard lying on a rock may have some awareness of the rock, but not $a s$ a rock. The bee which is guided in its flight by light is not aware of the light that impinges on it as light (Heidegger, Fundamental Concepts 198). This capacity for things to present themselves in such a way that they become manifest as having objective existence in each particular case distinguishes the human being from the animal. The capacity of the human being to attend to the objective existence of things is a necessary condition for the formation of a world. Animals captive to their environment and absorbed in the totality of instinctive drives are therefore "poorin-world." Heidegger retrieves the question of biological life only to effectively isolate the domain of the animal life from the domain of human existence:

The animal possesses this being-open (Offenheit) in its essence. Being-open in captivation is an essential possession of the animal...[T] he possession of being-open is a not-having, and indeed a not-having of world, if the potentiality for revelation of beings as such does indeed belong to the world. (Fundamental Concepts 391-392) 
Heidegger is surely not the first philosopher to separate animal life from human existence by turning to conceptuality and the comprehension of being that makes language possible. The human capacity to disclose entities as beings and ultimately to acknowledge the ontological difference between being and beings is what constitutes the framework for our background beliefs and the acquisition of language. Both Davidson and Heidegger would agree that without the capacity to apprehend the existence of things, animals lack language. In order to defend this unique capacity to comprehend being as the overriding condition for language, Heidegger turns to a decisively Greek understanding of conceptuality (ópı $\mu o ́ s$ ) by asserting that the human being with the capacity for conceptuality provides meaning to the world through discourse or

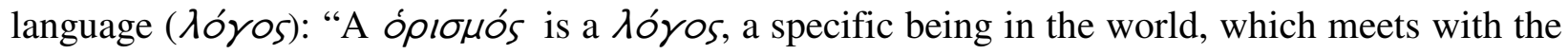
present world in its proper character of being-present (Da-character), it addresses it in its proper being" (Grundbegriffe 40). While Heidegger's project of fundamental ontology privileges the role of $\lambda o ́$ yos as the equiprimordial condition of being-in-the-world, he neglects to consider sufficiently the relation of $\lambda o ́$ yos to animality, i.e., how our comportment to the world through Aóyos is informed by our bodily comportment to the world as animals. Aristotle's own

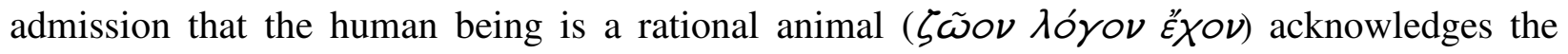
embodied nature of tóros. The development of this capacity ultimately depends upon the capacities we share with members of other non-human animal species. Contrary to Heidegger's

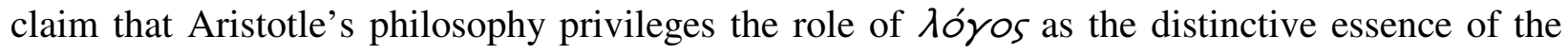
human being, it also may be argued that no philosopher has more extensively considered the

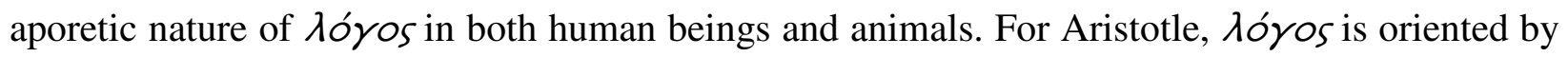
our capacity as animals to perceive the world. While prevalent within the human being as the 


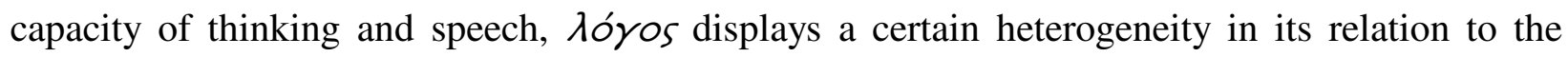
other capacities of the soul. Aristotle's treatises devoted to animality both curiously assume the hegemony of $\lambda o ́$ ros and equivocally call it into question. If we are to take seriously Heidegger's debt to Aristotle, we might begin by retrieving his interpretation of $\lambda o ́$ ros and its relation to these other capacities of life.

In his unpublished 1922 Aristotle Introduction, Heidegger investigates how being as a

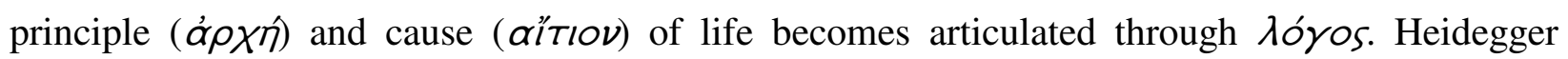
affirms the plurivocity of the word "life" being literally said in many ways ( $\pi \circ \lambda \lambda \alpha \chi \tilde{\omega} s$ $\lambda \varepsilon \gamma o ́ \mu \varepsilon v o \nu)$ as a fundamental phenomenon throughout the history of Greek-Christian interpretation. Life is to be understood as a middle-voiced phenomenon and therefore as a kind of movement or caring (curare), a "being-out-towards" (Aussein auf etwas) the world. ${ }^{6}$ The movement of caring is defined by the dealings (Umgang) which life has with its world as it is anticipated, oriented towards, and interpreted in its meaningfulness (Bedeutsamkeit). ${ }^{7}$ 1ó $\gamma o s$ is what originates this meaningfulness as a primordial directedness towards and absorption in the world. While גóyos possesses the capacity to distance itself from the world through theoretical reflection, it also produces an inclination towards falling into the world (Verfallensgeneigtheit) as its essential tendency (Hang) and innermost fate (Verhängnis). ${ }^{8}$ 1óros exhibits the tendency of falling towards the world and thereby being absorbed in the world because the world is tempting for life. If we are to disclose the meaning of $\lambda o ́$ ros and its relevance for the superficial

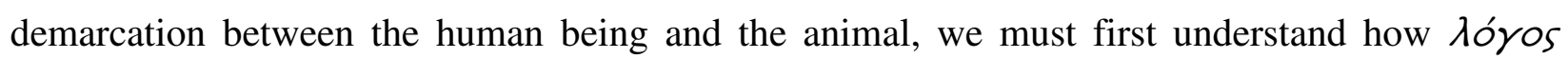

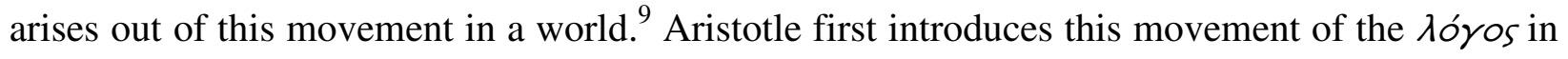
the Physics from which both his ontology and logic develop: "The central phenomenon, whose 
explication is the theme of the Physics, becomes the being in the How of its being-moved (Bewegtseins)" (PIA 26). Heidegger discloses the principles grounding the phenomenon of being as being-moved by examining the way in which the object has initially been given (KIVOúMEvov [what is moving]) and how it comes to be viewed: "The above research is characterized as $\dot{\alpha} \rho \chi \eta^{\prime}$

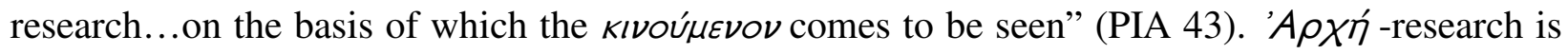
primarily critical by interrogating those principles that ground phenomena and are thus included in any pre-given interpretation. ${ }^{10}$ Aristotle's Physics functions as the first critical mode of access to the prior interpretations of the phenomena of nature (qúols) and being (oúoía) by introducing a new interpretation that is by definition (ópıouós) consonant with being-moved. Aristotle counters the static Eleatic conception of being with the determination of being as a phenomenon of movement (KIVOÚMEvov) and therefore as something which is capable of being-claimed and

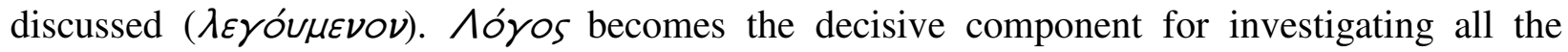
subsequent problems in the Physics: "What has been taken up as a theme of research, i.e., the

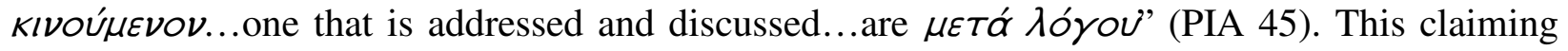

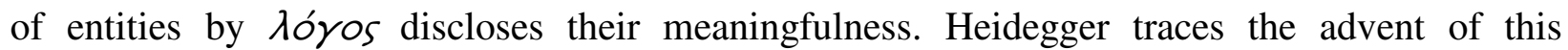
meaningfulness or being beginning with its primordial meaning as literally a having or possession (oúoía) that is available for use by being-produced. In production, the possession or having ( $\left.\varepsilon^{X} \mathcal{E} I \nu\right)$ of being comes into appearance (Anwesen). The starting point for an exposition of

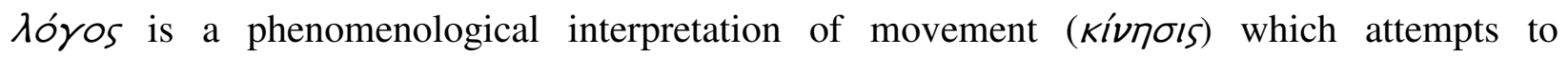
understand how the problem of being arises in relation to those objects which are produced and used in the world: 
The object field which provides the primordial sense of Being is the object field of those objects which are produced and used in dealings... That which is finished in the movement of the dealings of production (moinols), that which has arrived at its Beingpresent-at-hand (Vorhandensein), available for use-tendency, is that which is. (PIA 26)

Being-produced (moínols) is the being-available of that which can be grasped as an appearance ( $\left.\varepsilon i \delta \circ \delta_{S}\right)$ and thus claimed and discussed $\left(\lambda \varepsilon^{\prime} \gamma \varepsilon l \nu\right)$. The ontological structures which determine the course of human life are conditioned by the relation between the objects of the dealings and the ways of claiming and discussing which belong to these dealings.

While the world comes to be disclosed by encountering the entities in these dealings as

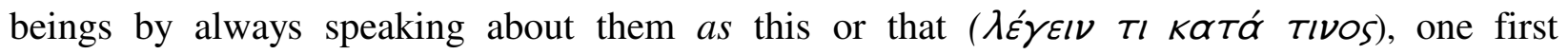
encounters these entities by being-moved and being affected ( $\left.\pi \alpha \sigma^{\sigma} \chi \varepsilon l \nu \tau l\right)$ by them. The

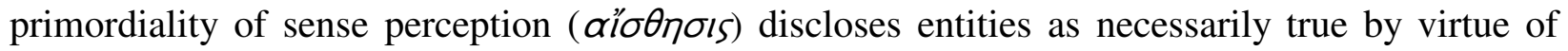
how they appear to us. Since sense perception is an originary openness which binds both humans and animals together in their finite receptivity to the world, one must begin to understand this capacity of being-moved and being-affected as grounding the possibility of world disclosure. If

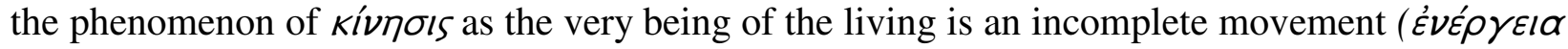
$\dot{\alpha} T \varepsilon \lambda \dot{\eta} S$ ), then the possibility of being-affected only arises from this essentially incomplete openness as the most fundamental indication of finitude. Here one would also have to include the phenomenon of $\lambda o ́ \gamma o s$ as harboring within itself this primordial mádos of affectivity. While

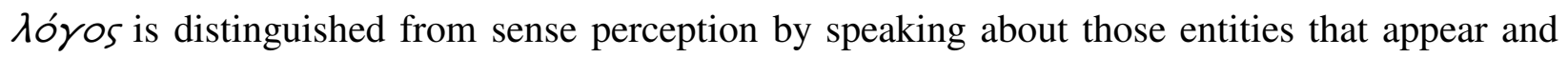
thereby risking the possibility of falsity, גóyos shares a kinship with sense perception in this ability to take up the object before distinguishing it as something ( $\sigma u ́ v \theta \varepsilon \sigma / s)$ by explicitly asserting ( ómó $\phi \alpha v \sigma / \zeta)$ how it appears: 
What it says is said on the basis of this object and is drawn from (ámo) it. Accordingly,

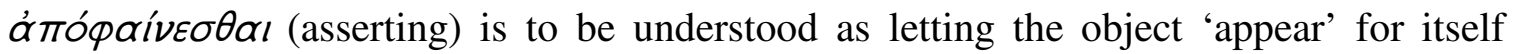
(middle voice) from out of itself and as it is in itself. (PIA 32)

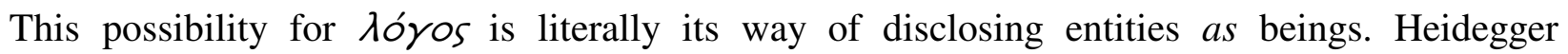
investigates Aristotle's definition of $\lambda o ́$ yos as this finite limit which orients the human being by choosing between the possibilities of assertion and non-assertion, thereby distinguishing that which is said from that which remains unsaid. Every saying or asserting is a bringing together or

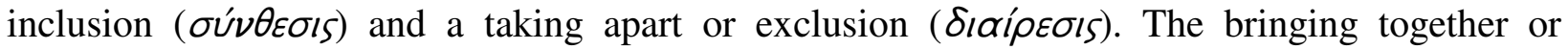
included possibility that an object is white is always posited together with the excluded possibility that the object is not white. ${ }^{11}$ Throughout De Anima, Aristotle even describes how sense perception possesses its own unique mode of $\lambda o ́$ ros:

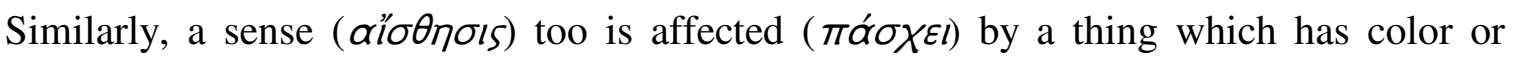
flavor or sound, not insofar as that thing is signified by its name, but insofar as it is suchand-such (i.e. colored or flavored or sounding) and according to the corresponding

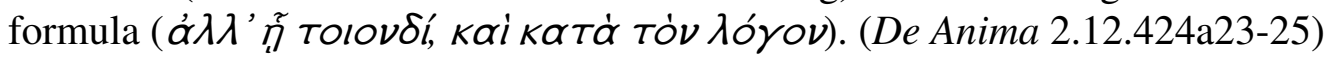

Heidegger privileges $\lambda o ́$ yos as the distinctive essence of Dasein, yet does not sufficiently

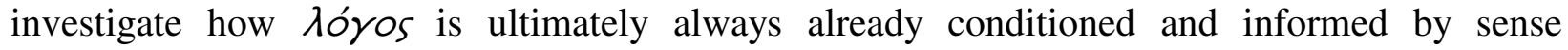

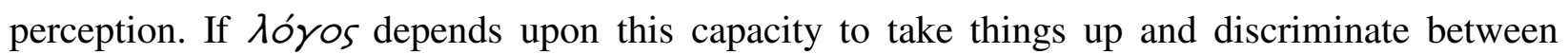
them in and through the same modality of sense perception we share with members of other animal species, we must begin to reconfigure our understanding of the primacy of $\lambda o$ yos as exclusive to the human domain. ${ }^{12}$ Perhaps $\lambda o ́$ yos is no longer the distinguishing hegemonic attribute of the human species but a capacity shared with other animals for the sake of living well. In the final paragraph of De Anima, Aristotle even alludes to the capacities of sense

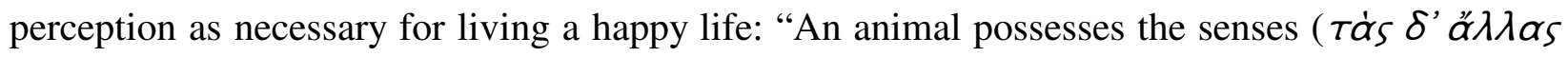




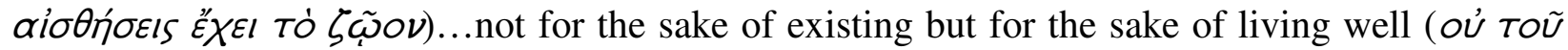

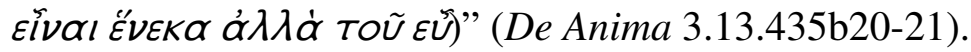

For Aristotle, human existence both includes and excludes animal life. Human existence is separated and opposed to animal life with $\lambda o ́$ ros while always already maintaining a relation to animal life with sense perception. ${ }^{13}$ With the capacities of sense perception and $\lambda o ́$ yos, living beings are thrown into the world as the embodiment of their finitude and thereby open to the movement of unconcealment $\left(\alpha^{\prime} \lambda \eta^{\prime} \theta \varepsilon l \alpha\right) .{ }^{14}$ How are we to determine that the animal is "poor-in-

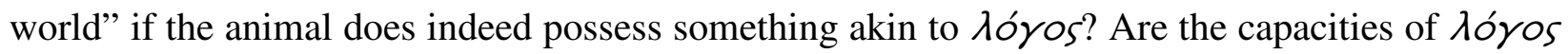
within the human and the animal too distinct to be considered in their unity? It is not insignificant that throughout De Anima, Aristotle continuously returns to probe this enigmatic relation between $\lambda o ́$ ros and sense perception which supposedly demarcates human existence

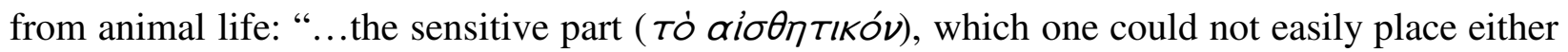

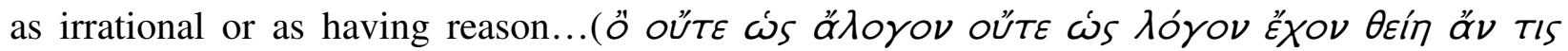
'podíws)" (De Anima 2.13.432a30f). ${ }^{15}$

Perhaps the greatest perplexity in the traditional hierarchy of the soul arises when Heidegger considers the relation between $\lambda o ́$ yos and the highest human capacity of cognition, the intellect (voũs). Aristotle claims that the activity of thinking (vónols) as the immediacy of perceiving and having-perceived best expresses the idea of pure movement or being-moved. The

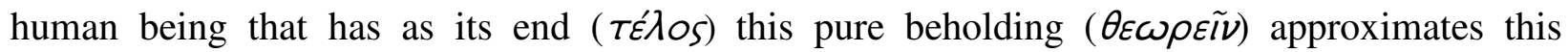
condition. ${ }^{16}$ For Aristotle, the intellect fulfills its explicit function only within this rarified domain of $\theta \varepsilon \omega \rho \varepsilon \tilde{I}$ and therefore cannot be submitted to the theoretical and practical distinction 


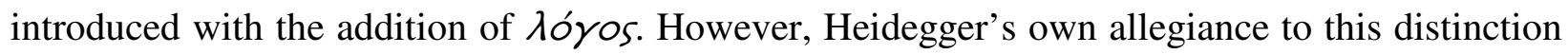
too hastily privileges how the theoretical function of the intellect comes to be critically disclosed

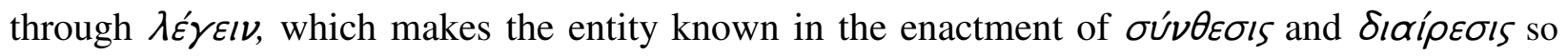
that the intellect comes to be understood as a discursive mode of thinking ( $\delta ı \alpha-\nu o \varepsilon i \tilde{\sigma} \theta \alpha l)$. While entities are discursively encountered by being claimed through the articulation of $\lambda \varepsilon^{\prime} \gamma \varepsilon l \nu$, the intellect as presented by Aristotle is ideally to remain unarticulated and without discourse $(a ́ \lambda o ́ \gamma O \nu)$ as a pure perceiving which produces illumination for the mode of theoretical

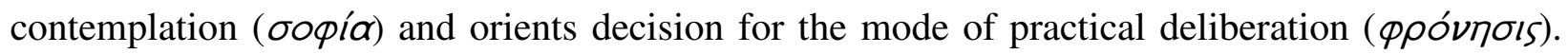
The intellect operates analogously with the immediacy of sense perception insofar as it brings to entities their direct givenness as they are disclosed. The look or appearance of entities ( $\varepsilon i \delta \circ s)$ is produced by the intellect which orients גóros - to claim the entity as a being. The intellect is what grasps the first principles or universals that illuminate being. The receptive openness of sense perception and the intellect to encounter and discover entities as beings seems to fulfill a homogeneous function within the soul which only complicates their alleged separation. Both also disclose a certain heterogeneity in their aporetic relation to the other capacities. The intellect shares with sense perception a pure and simple perceiving, yet this immediacy retained throughout Aristotle's exposition is called into question by Heidegger once he begins to consider how the intellect interacts with tóyos. If the pure intellect also possesses a discursive capacity to interact with the $\lambda o_{\gamma}$ os, how does it still retain its non-discursive immediacy to grasp these first principles as its distinguishing attribute? If the boundaries separating the intellect from

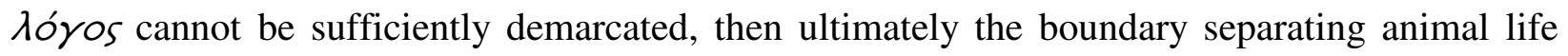
from human existence becomes an even more perplexing question. 
This ambiguity is particularly telling when we examine how the intellect is involved in deliberation for the sake of a decision. Aristotle describes this practical deliberation as foresight ( $\rho \rho o ́ v \eta \sigma / s)$, which curiously applies to both humans and animals: "It is in view of this that people say that some beasts too are prudent, namely those which appear to have the power of foresight ( $\delta \dot{v} \nu \alpha \mu ı \nu$ mpovontıkńv) with regard to their own way of life" (Nicomachean Ethics 6.7.1141a27-29). Foresight is characterized by an intentional structure of knowing one's way around in the world in order to distinguish between competing alternatives, and thus is always conditioned by $\lambda o ́$ yos directed towards particular dealings in the world as a seeing with respect to the moment of decision. If some animals indeed possess foresight and the ability to deliberate about a future decision, what genuine condition remains to privilege human existence? Aristotle unfortunately subordinates this movement of foresight as contingent upon the movement of

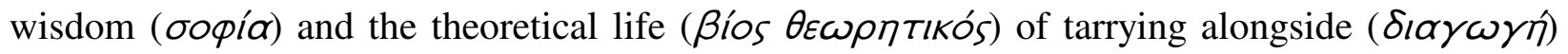
the world in contemplation as the most proper mode of being fully present. ${ }^{17}$ Aristotle's conception of this authentic Existenz essentially removes and effectively isolates the movement of $\lambda o ́$ yos from its own essential thrownness of being-alongside and fallen into the world.

\section{Reviving Fundamental Ontology}

Heidegger's projected conclusion to his never-published treatise on Aristotle aimed to retrieve another beginning of $\lambda o ́$ yos in its being-alongside and being-affected by the world by turning to Metaphysics Z, H, and $\Theta$, De Motu Animalium, and De Anima. The ontological horizon of $\lambda o_{\gamma}$ os originates from the phenomenon of being as being-moved (Bewegtsein):

What is shown here is how Aristotle develops the fundamental problem of beingness [Seinshaftigkeit] through a specifically executed explication of what is claimed in a 


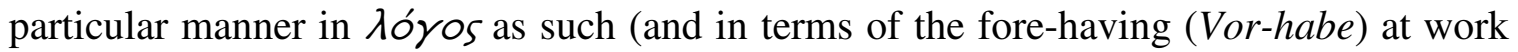
here, this $\lambda o_{\text {yos }}$ is at the same time the look of something being moved in some way,

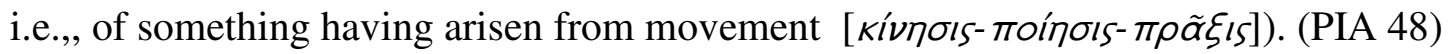

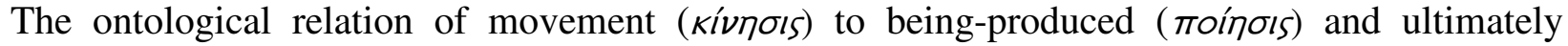
human action $(\pi \rho \tilde{\alpha} \xi 15)$ merits an interpretation of De Anima and De Motu Animalium devoted to explicating the being of life as a particular kind of movement. ${ }^{18}$ The intentionality of the living is conditioned by the objectivity of the world insofar as movement is "noetically" illuminated when it goes about its dealings in that world. This being-out-for and -towards (Aussein auf etwas) which motivates the noetic illumination of entities in the world as beings

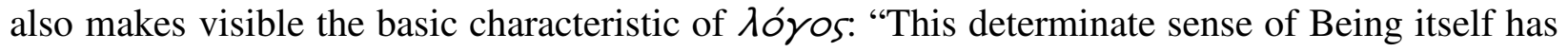
its origin in the primordially given world environment; but then even with Aristotle himself it loses its sense of origin under the pressure of a determinate ontology..." (PIA 50-51).${ }^{19}$ Already in Aristotle and throughout the subsequent history of ontological research, tóros has lost the primordial relation to its origin in being-moved by the world and therefore must be recovered by investigating the living ontological movement of its embodied existence.

When examining Heidegger's debt to Aristotle, we must return to his original motive for privileging גóros in relation to the other capacities of the soul. Throughout De Anima, Aristotle describes the soul as an essential openness to the possibility of entities disclosing themselves ${ }^{20}$ If

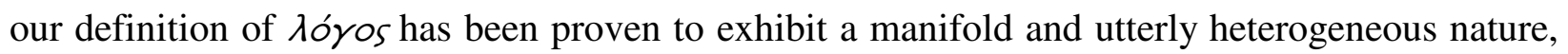
then the capacities of the soul are also to be considered as occupying this same ambiguity. By the time of the composition of Sein und Zeit, Heidegger does not consider why the capacities of the soul deserve further hermeneutical explication and only returns to De Anima in order to describe the human soul as constituted by the twin capacities of sense perception and intellect: 


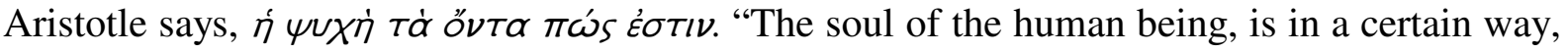
entities." The soul which makes up the being of the human being has aesthesis and noesis among its ways of being, and in these it discovers all entities, both in the fact that they are, and in their Being as they are - that is, always in their Being. (Sein und Zeit 14)

Throughout the existential analytic of Sein und Zeit, Heidegger thoroughly conceals the fateful link between the zoological residue of sense-perception and the distinctive ontological role of the intellect by neglecting to consider the capacity of sense perception to discover and distinguish between entities by the primordial disclosedness of how we find ourselves (Be-findlichkeit) attuned to the world through the opacity of our moods (Stimmungen). The valorization of the intellect to disclose the existence of these entities as they are encountered in everyday dealings effectively prioritizes Dasein over all other living beings worthy of ontological clarification. This unbridgeable separation between fundamental ontology and zoology betrays an anxiety which haunts the history of metaphysics and his own thought. ${ }^{21}$ The capacity of the animal to possess גóros raises a series of ontological questions regarding the boundary between the human and the animal which deserve a more sufficient investigation. ${ }^{22}$ What are the consequences for retrieving the project of the fundamental ontology according to this reinterpretation of $\lambda o ́$ ros as a mode of living movement? Moreover, how does our reconception of tóros impact our understanding of Aristotle's own ontology? Perhaps this retrieval of גóros in its heterogeneity might encourage further research into the enigma of the living and promote a revival of $z o$ ontology as the ground of Heidegger's thinking.

\section{Notes}

${ }^{1}$ Bugnyar 69-76. The same experiment is cited in Berreby 20; and Grandin 244.

${ }^{2}$ Bugnyar and Heinrich 1641-1646. 
3 Temple Grandin analyzes Marion Stamp Dawkins' criteria for true cognition in Animals in Translation, 243-254. Another experiment conducted by the biologist Brian Hare of Harvard and Michael Tomasello of the Max Planck Institute for Evolutionary Biology in Leipzig investigated how ordinary domestic dogs understand what is meant when their owners point at something. The experiment suggests that dogs, through centuries of selective breeding, possess a capacity to read the minds of their owners. Cf. Hare and Tomasello, 1636-1639.

${ }^{4}$ Davidson's defense of a language-bearer as possessing a scheme of propositional attitudes is a response to N. Malcom's "Thoughtless Brutes," Proceedings and Addresses of the American Philosophical Association, no. 46 (1972-1973): 5-20.

${ }^{5}$ Heidegger, Fundamental Concepts 259. See also McNeill 197-248; and Agamben, The Open 49-62.

6 Heidegger's designation of caring as "being out towards" (Aussein auf etwas) is noted by Gadamer: "Der andere Antrieb, dem er folgt und der damals sogleich, vor allem von der protestantischen Theologie, aufgenommen wurde, war der Appell an die Eigentlichkeit des Daseins, die es galt, in der Faktizität des Daseins bei ARISTOTELES wiederzufinden. Es ist das "Aussein auf etwas" was Heidegger hier am Ende sogar in HUSSERLS phänomenologischer Lehre von der Intentionalität wiederzufinden meint. Auch darin liegt eine enorme Überzeugungskraft. Es gibt vielleicht nur ein einziges Wort, das die Problematik des HEIDEGGERshcen Versuches verrät, an dem er später nicht mehr hat festhalten wollen. Ich meine dies, daß er das Wort "Durchsichtigmachen" sehr oft gebraucht. Die Erhellung die das menschliche Dasein von sich aus sucht, bestehe vor allem darin, da $\beta$ sich durchsichtig wird und auf diese Weise trotz aller eigenen Bedingtheit einen seine eigenen Möglichkeiten ergreifen läßt" (233).

${ }^{7}$ Heidegger provides his first concrete explication of circumspection (Umsicht) which will function as a critical component of understanding (Verstehen) throughout the existential analytic of Sein und Zeit, 142-153. Many commentators have noted Heidegger's continued appropriation

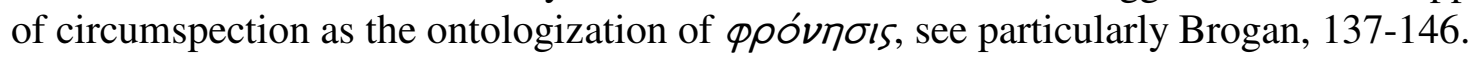

${ }^{8}$ Heidegger claims that ruinance characterized by fallenness is a basic character of caring which is otherwise determined by the facticity of being-thrown into a world. Thrownness is Dasein's alreadiness (Gewesenheit) which temporally corresponds to the fallenness of presenting (Gegenwart) and the pursuit or future becoming (Zukunft) of alreadiness (Gewesenheit), see especially the second division of Sein und Zeit: "But taking over thrownness signifies being Dasein authentically as it already was. Taking over thrownness, however is possible in such a way that the futural Dasein can be its ownmost 'as- it-already-was'-that is to say, its 'been' [sein "Gewesen"]" (326).

${ }^{9}$ Aristotle, Metaphysics 7.4.1030a9-10, 322-323: To state or assert something is nothing other

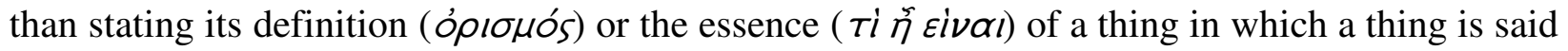


to be by virtue of itself ( $k \alpha \theta^{\prime} \alpha \dot{u} \tau o$ ). Thus, there is an essence ( $\tau i \eta^{\zeta}$ Eival) only of those things

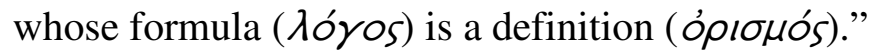

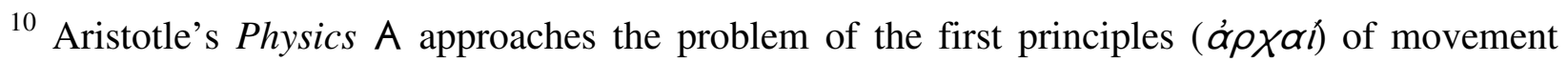

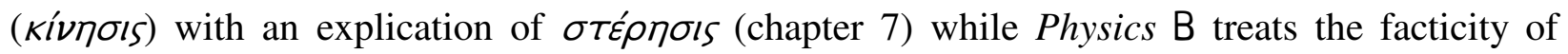
natural beings ( explaining its primordial structures, namely $\delta \dot{v} v \alpha \mu l s$ (potentiality), i.e., the in each case

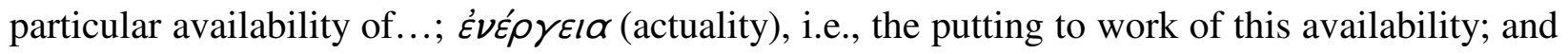

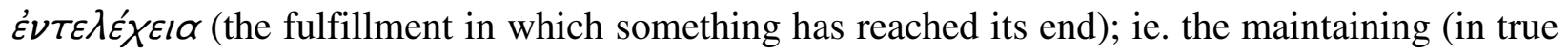
safekeeping) of this availability that has been put to work.

11 Thomas Sheehan examines the contribution of Heidegger's analysis of $\sigma u ́ v \theta \varepsilon \sigma / s$ and Sıaipeols to the movement of Dasein: "In the oral version of the course, Die Grundbegriffe der Metaphysik (February 27 1930) Heidegger said that diairesis seen as human transcendence, 'pulls us asunder as it were, and grants us a stretching ahead, takes us away into the possible...' But at the same time the human being returns from that transcendence to entities so as to know them in terms of possibility, i.e., 'so as to allow the possible - as what empowers the actual - to speak back to the actual in a binding way'... binding or bonding it: synthesis" (80).

12 Claudia Baracchi writes: "Obliquely, and in a fragmentary fashion, in the margins of his main discourse, Aristotle seems to outline a questioning of human specificity with respect to other animals. This does not mean that human uniqueness is denied -but that it is questioned precisely as one tries to delineate it, that the specifically human mode of animality remains in and as question, that its boundaries are transgressed precisely as they are traced and present themselves in their dynamic shifting" (237).

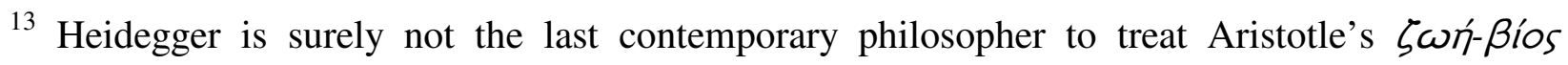
distinction. Agamben's Homo Sacer provides a genealogical history of the distinction in Arendt and Foucault before its culmination in Agamben's own bio-politics: "The fundamental categorial pair of Western politics is not that of friend/enemy but that of bare life/political existence, zoé/bios, inclusion/exclusion. There is politics, because man is the living being, who in language, separates and opposes himself to his own bare life and, at the same time, maintains himself in relation to that bare life in an inclusive exclusion" (8).

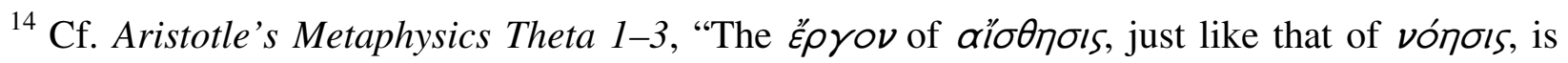
$\dot{\alpha} \lambda \eta \dot{\theta} \theta \varepsilon ı \alpha$ - -the openness of beings, and in a special manner the perceptibility of things" (168). After juxtaposing Aristotle with Protagoras, Heidegger concludes: "Aristotle was not capable of comprehending, no less than anyone before or after him, the proper essence and being of that

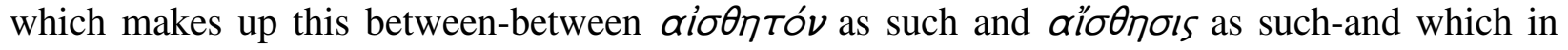
itself brings about the very wonder that, although it is related to self-reliant beings, it does not through this relation take their self-reliance away, but makes it possible for such being to secure this self-reliance in the truth" (Heidegger, Aristotle's Metaphysics Theta, 1-3 173). 
${ }^{15}$ Cf. Aristotle's Metaphysics Theta 1-3: "We must above all adhere to what Aristotle presents

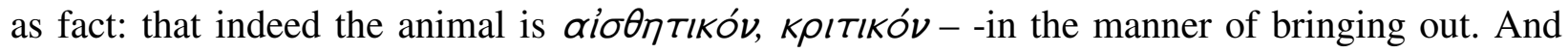
just as little as we are allowed to shove aside the developed meaning of $\lambda o ́$ ros in the sense of conversance. For the matter surely demands that we do not deny $\lambda o ́$ yos to the animal as it now stands - -or else leave the question open. And this is just the position that Aristotle takes

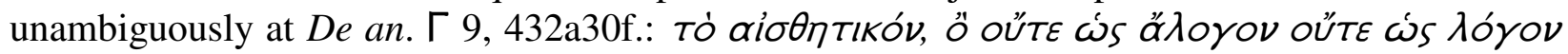

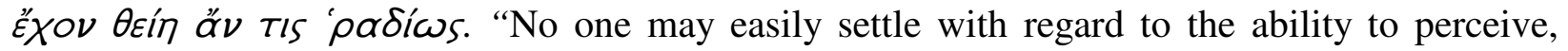
whether this is a capability without conversance or a conversant capability." This caution with regard to deciding and questioning must even today remain for us exemplary, irrespective of the further question of where the essential boundary runs between animal and human" (Heidegger, Aristotle's Metaphysics Theta, 1-3 107).

16 Throughout “Phänomenologische Interpretationen zu Aristoteles," Heidegger interprets voũs according to Aristotle's definition of $\pi \rho \tilde{\alpha} \xi ı$ in the Metaphysics (1048b33). Nónols as a pure $\theta \varepsilon \omega \rho \varepsilon \tilde{\nu}$ or beholding has its principles of beginning and end in itself, "such movement is a kind of being that consists in both a temporalizing and unfolding of itself that takes itself in true safekeeping and a taking itself into true safekeeping that temporalizes and unfolds itself" (verwahrenden Zeitigung als zeitegender Verwahrung) (39).

17 Heidegger continuously brings into contrast the finite contingency of $\varphi \rho o ́ v \eta \sigma / s$ with the eternal and divine nature of oopía constitutive of the movement of a pure-beholding or voũs, "first as pure and simple perceiving, voũs is in its genuine movement when it has given up all concern for orienting beings in certain directions and only perceives. Second, as this perceiving, it is a movement that, in having arrived at its end insofar as what it is able to perceive in a pure and simple manner now stands before its gaze, not only does not cease, but rather now-precisely as having arrived at its end-really is movement for the first time" (38).

18 Heidegger concludes "Phänomenologische Interpretationen zu Aristoteles" by retrieving the lost primacy of moínoıs as a mode of kívnols and therefore neglects to develop Dasein as an ontological determination of $\pi \rho \tilde{\alpha} \xi ı$. This concept will be taken up more extensively in Grundbegriffe der aristotelischen Philosophie.

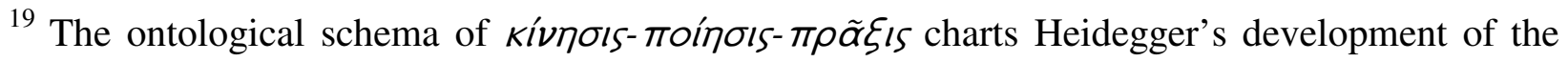

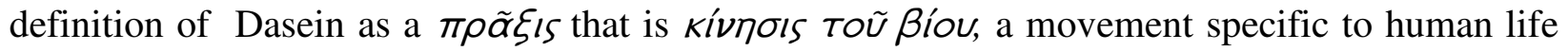
(1220 b27) to $\pi \rho \tilde{\alpha} \xi ı$ as $\varepsilon \dot{\nu} T \varepsilon \lambda \varepsilon^{X} \varepsilon l \alpha$ or having an end in itself (1048 b33).

${ }^{20}$ De Anima 2.11.424a1, 136-137: "For to sense is to be affected in a certain way ( $T \dot{o}$ ró $\rho$

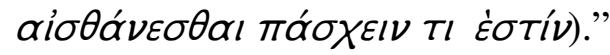

${ }^{21}$ Cf. Sein und Zeit: "In the order of possible understanding and interpretation, biology as the "science of life" is rooted in the ontology of Dasein, although not exclusively in it. Life has its own kind of being, but is essentially accessible only in Dasein. The ontology of life takes place by way of a privative interpretation. It determines what must be the case if there can be anything 
like just-being-alive (Nur noch leben). Life is neither pure objective presence, nor is it Dasein. On the other hand, Dasein should never be defined ontologically by regarding it as life (ontologically undetermined) plus something else" (49-50).

${ }^{22}$ Cf. Aristotle's Metaphysics Theta 1-3: "On this point, I am leaving aside the difficult passage

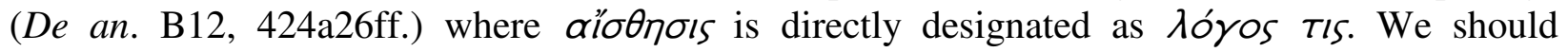
understand $\lambda o ́$ yos in this passage neither merely as relationship, nor simply as reason or discourse in the sense of language; rather, what is in fact meant by $\lambda$ ó 05 TIS is the perceiving exploration of..., and the conversant relating to..., the relation which takes cognizance of its surroundings, the relation to what presents itself in the surroundings as lying opposite,

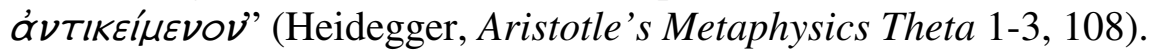

\section{Works Cited}

Aristotle. De Anima. Trans. W.S. Hett. Cambridge: Harvard University Press, 1937.

—. Metaphysics. 2 vols. Trans. H. Tredennick. Cambridge: Harvard University Press, $1933 / 1935$.

—. Nicomachean Ethics. Trans. H. Rackham. Cambridge: Harvard University Press, 1934.

—. Physics. 2 vols. Trans. P.H. Wicksteed and F.M. Cornford. Cambridge: Harvard University Press, 1929.

Agamben, Homo Sacer: Sovereign Power and Bare Life. Trans. Daniel Heller-Roazen. Stanford: Stanford University Press, 1998.

—. The Open: Man and Animal. Trans. Kevin Attell. Stanford: Stanford University Press, 2004.

Baracchi, Claudia. "The Nature of Reason and the Sublimity of First Philosophy: Toward a Reconfiguration of the Aristotelian Interpretation." Epochē 7, no. 2 (Spring 2003): 223250.

Berreby, David.“Deceit of the Raven.” New York Times Weekly Magazine. 9/4/05: 20-21.

Brogan, Walter. "Heidegger and Aristotle: Dasein and the Question of the Practical Life." Crises in Continental Philosophy. Ed. Arleen Darley and Charles Scott. Albany: State University of New York Press, 1990. 137-146.

Bugnyar, T. and K. Kotrschal. "Leading a Conspecific Away from Food in Ravens (Corvus Corax)?" Animal Cognition, 7, no. 2 ( 2004): 69-76. 
Bugnyar, T. and B. Heinrich. "Food storing ravens differentiate between knowledgable and ignorant competitors." Proceedings of the Royal Society London Series B 272 (2005): 1641-1646.

Davidson, Donald. “Thought and Talk.” Inquiries into Truth and Interpretation (Oxford: Clarendon Press, 2001. 155-170.

Dawkins, Marion Stamp. Through Our Eyes Only? The Search for Animal Consciousness. New York: Oxford University Press, 1998.

Derrida, Jacques. Rogues: Two Essays on Reason. Trans. Pascale Anne-Brault and Michael Naas. Stanford: Stanford University Press, 2004.

Gadamer, Hans-Georg. "Heideggers theologische Jugendschrift." Dilthey Jahrbuch für Philosophie und Geschichte der Geisteswissenschaften Bd. 6 (1989): 238-234.

Grandin, Temple. Animals in Translation: Using the Mysteries of Autism to decode Animal Behavior. New York: Scribner, 2005.

Hare, B., Brown. M., Williamson, C., and M. Tomasello."The domestication of social cognition in dogs." Science, no. 298 (2002): 1636-1639.

Heidegger, Martin. The Fundamental Concepts of Metaphysics: World, Finitude and Solitude. Trans. William McNeill and Nicholas Walker. Bloomington: Indiana University Press, 1996.

—. Sein und Zeit. Tübingen. Niemeyer Verlag, 1979.

-. Grundbegriffe der aristotelischen Philosophie. Ed. Mark Michalski. Frankfurt am Main: Vittorio Klostermann, 2002.

—."Phänomenologische Interpretationen zu Aristotles (Anzeige der hermeneutischen Situation)." Dilthey Jahrbuch für Philosophie und Geschichte der Geisteswissenschaften Bd. 6 (1989): 237-269.

-. Aristotle's Metaphysics Theta 1-3: On the Essence and Actuality of Force. Trans. Walter Brogan and Peter Warnek. Bloomington: Indiana University Press, 1995.

Heinrich, Bernd. Mind of the Raven: Investigations and Adventures with Wolf-Birds. New York: Harper, 2006.

McNeill, William. "Life beyond the Organism: Animal Being in Heidegger's Freiburg Lectures 1929-1930." Animal Others: On Ethics, Ontology, and Animal Life. Ed. H. Peter Steeves. Albany: State University of New York Press,1999.197-248

Sheehan, Thomas. "Hermeneia and Apophansis: The early Heidegger on Aristotle." Heidegger et idée de la phénoménologie. Dordrecht: Kluwer Academic Press, 1988. 67-80. 